\title{
Cautery Device
}

National Cancer Institute

\section{Source}

National Cancer Institute. Cautery Device. NCI Thesaurus. Code C50345.

A device designed to coagulate and seal blood vessels or to destroy tissue with heat or electric current. 